\title{
China - Miracle Or Mirage
}

Morris K. Speter, (Email: Kmoshe1@yahoo.com), College of Mount Saint Vincent

\begin{abstract}
For centuries China has been seen as a backward country. It was dominated by the European powers and, since the middle of the last century, by a very doctrinaire communist government. However, in the last 10 - 15 years China has emerged as an economic giant with an economy growing at 10\% + per annum operating in a decidedly capitalistic fashion. Thus, we have the paradox of an anti communistic economic system operating under an anti capitalistic political system. The question for the future is whether this economic miracle will continue into the $21^{\text {st }}$ century or is it but a temporary mirage and China will revert back to its previous secondary role on the world's stage?
\end{abstract}

Keywords: Capitalism, China, Communism, Culture, Future, Population, Pollution.

\section{INTRODUCTION}

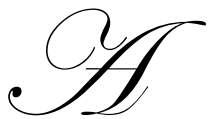

s we study the history of the world we have a decidedly western perspective. Our cultural, religious, legal and economic systems have evolved over the millennia starting with our perception of history. We look at the beginning of history through the prism of a Middle Eastern and European foundation with the incorporation of the rest of the world regions coming at a later date. These "other" regions are included, in our more recent history, primarily, as a function of how the European countries interacted with them.

The Americas are known, to us, as a result of the Spanish/Portuguese and later English/French explorations. The Inca, Aztec, and Maya cultures that predated the European "discovery of the New World" are seen as but a footnote in history. Similarly, the great nations of the Far East (e.g. China) are also only recognized as a function of the European interactions with them. Though their existence was known from Roman times it was Marco Polo's visit in the $13^{\text {th }}$ century that brought China to the forefront of European consciousness. French/British and Portuguese explorers in the $15^{\text {th }}$ century pulled China into the history we are familiar with. It was viewed as a weak China, a pawn of the western powers that had no worthwhile intrinsic value other than producing silk for western markets and being a market for western products. It was the classic colonial model.

However, China has as long and illustrious history as the West. Their imperial conquests rivaled the Babylonian, Persian, Egyptian, Greek and Roman empires we base our history on. China's technological achievements and culture were, in many ways, superior to the west. Among their inventions are paper and gunpowder. They also built the only man made structure visible from space, the Great Wall. The Chinese history of greatness and then decline reached its nadir during the last century as Japan invaded and destroyed most of the country just prior to and during World War II. Following the war a conflict between Communist and Nationalist forces further devastated the country. Finally, their so-called "Great Leap Forward" between 1966 and 1976 actually took the country backwards.

Over the last 10-15 years China has emerged as an economic Colossus. With a GDP annual growth rate of $10 \%+$ China has become the world's manufacturing center, accumulating a foreign exchange reserves exceeding $\$ 1$ trillion. They are developing the world's largest hydroelectric project, and building numerous buildings that will be the tallest in the world, when completed. These developments are occurring under a somewhat laissez-faire economic system. Yet, all the while, China remains a hard line Communist dictatorship 
This paradox raises the question that is critical to the future of the world. Is China's economic miracle of recent vintage going to continue into the $21^{\text {st }}$ century or is the current situation more of a mirage and the China of the future, once again, becomes a secondary player on the world's stage?

\section{FACTORS}

When trying to forecast China's future it is useful to consider a number of macroeconomic areas. Following is an analysis of these factors:

\section{Demography}

China's history has always been driven by demographics. Currently the world's most populous country China has had a very large population for all of its history; China has always struggled just to feed its people. This factor resulted in China passing a "one child per family" law that was rigidly enforced. As a result of this law China's population growth has reversed and its total population probably peaked. Unintended consequences of this law include:

1) a large and rapidly increasing population segment of elderly Chinese that require support (see Figure - 1)

2) a decreasing proportion of young people to work and produce goods and services (see Figure -1)

3) a gender imbalance that created a surplus of Chinese males, as compared to available female mates (currently 134 males born for every 100 females)

4) a breakdown in the traditional extended family structure with an increasing emphasis on self reliance rather than family support

Consequently, it is likely that China will soon lose its position as the country having the largest population in the world (to India). Also having a large population had many positive economic benefits to China ranging from lower labor costs of production to having a large internal market for consumption. The question for the Chinese is whether to devote an increasing proportion of their resources to support their aging population or to invest these same resources in the development of their economy?

Figure1: China's Age Distribution 1950 to 2050

\section{CHINA'S POPULATION \\ IN BILLIONS}

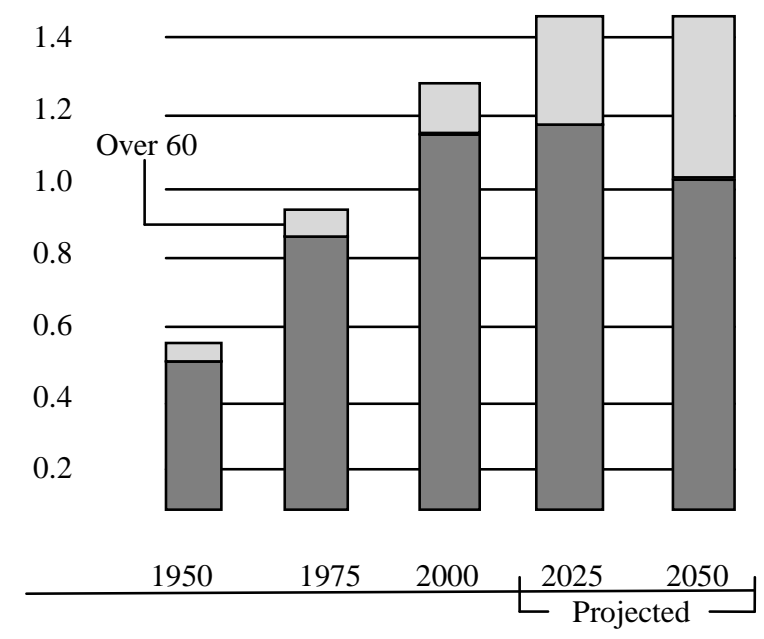

Source: United Nations Department of Economic and Social Affairs 


\section{Economy}

The economy of China is booming today. It will shortly become the largest consumer market in the world for everything ranging from cars and cellular phones to clothes and cosmetics. That huge demand is a simple outcome of being the country with the largest number of people recently becoming a consumption oriented society. Today, in China, there's a seeming economic frenzy of activity to make up for centuries of neglect. With its high GDP growth rate China is fast closing in on the Europe and the United States in terms of the world's GDP distribution (see Figures -2). This increase in GDP over the last 50 years still has not brought China back to the levels it enjoyed from 1600 to 1900 (see Figure -3).

Figure 2: 1980-2006

Share of World GDP*, Percent of Total

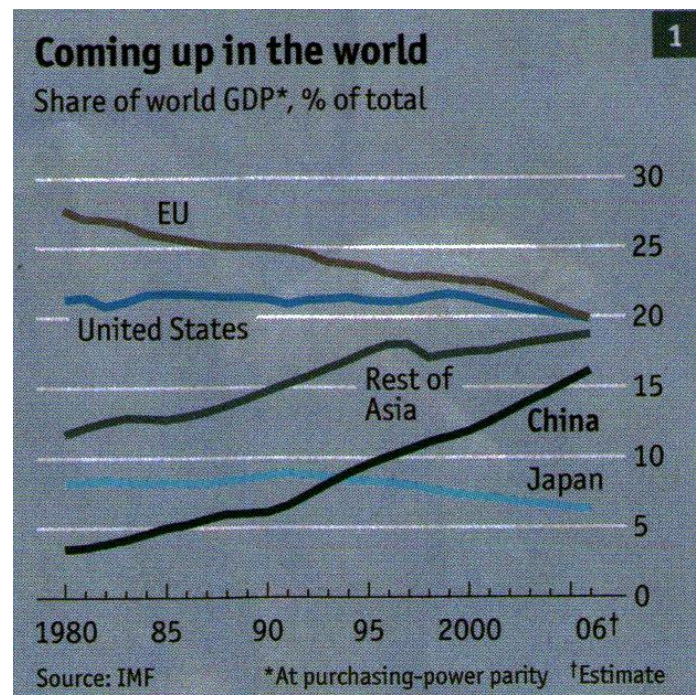

Source: International Monetary Fund
Figure: 3 1600-2006

Share of World GDP* Percent of Total

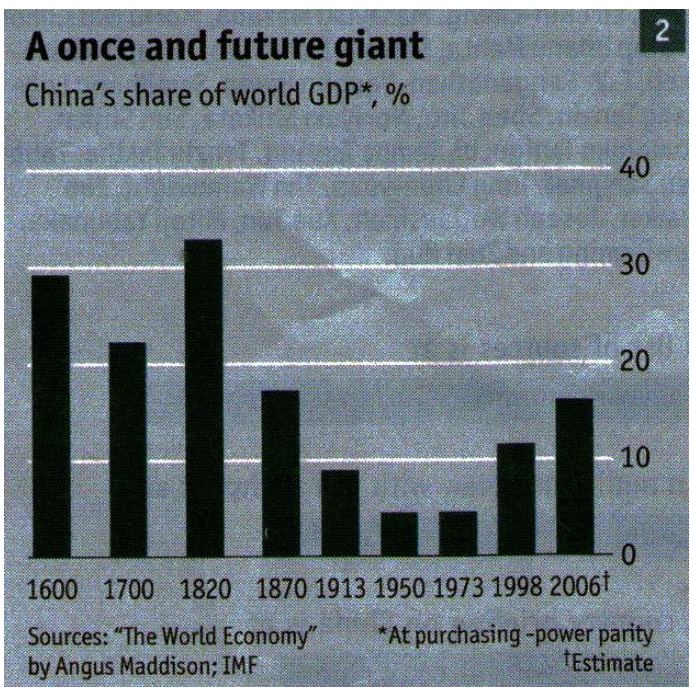

* at Purchasing Power Parity

However, there are costs associated with growth and economic principles (e.g. laws of supply and demand) that apply. For example, the increase in purchasing power has created a boom for the auto industry resulting in massive traffic jams and very high pollution levels. Increasing demand has led to increasing inflation (see figure-4)

Figure 4: Year over year Change in Consumer Prices

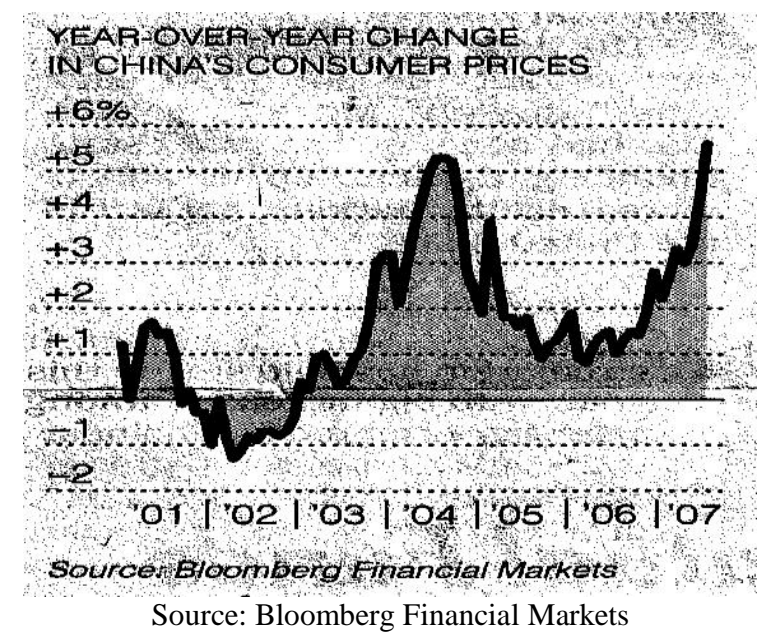


As the US and other world economies have learned economic performance moves in a cyclical pattern. Economic busts follow economic expansion. In China we have had the expansion part for a number of years and not yet the economic downturn that is bound to happen. The extent, severity and reaction to such a recession are a major factor in determining the future success of China

\section{Environment}

As noted above one of the costs of economic development is pollution. China today is one of the world's most polluted countries (see Figure-5). There's heavy smog in the air from car exhaust and coal fired plants used to generate electricity. The water and land are poisoned by human and industrial waste. China today has become the largest contributor to global warming.

Figure -5 Selected Countries Environmental Success Index

"Green" score measured indicators such as energy efficiency and carbon-dioxide emissions "Brown" score includes indicators such as quality of drinking water, air pollution and sanitation

\begin{tabular}{llccc} 
Country & Green & Brown & Average & Rank \\
\hline Sweden & & & & 84.2 \\
New Zealand & 69.3 & 99.1 & 84.1 & 2 \\
Finland & 70.6 & 97.7 & 83.0 & 3 \\
Czech Republic & 67.8 & 98.3 & 81.3 & 4 \\
United Kingdom & 66.6 & 95.9 & 81.1 & 5 \\
United States & 63.6 & 98.5 & 73.5 & 32 \\
China & 49.5 & 97.6 & 54.6 & 92 \\
Mali & 49.4 & 59.8 & 35.0 & 130 \\
Mauritania & 62.1 & 7.9 & 31.8 & 131 \\
Chad & 35.4 & 28.3 & 30.8 & 132 \\
Niger & 61.7 & 0.0 & 27.4 & 133 \\
\hline
\end{tabular}

Source: Pilot Environmental Performance Index, Yale and Columbia Universities

The outlook for the future is more ominous. With a population roughly four tines that of the United States the Chinese currently live at a much lower standard. As China aspires to become more western and become equal to the west its need for resources will overwhelm the planets capabilities.

Unless China acts vigorously, it will literarily choke on its own waste. Cleaning up the air, water, and land will incur substantial costs. Money will have to be diverted from the production economy to invest in a clean economy. This refocus of priorities is critical not only for the health of China but also for the wealth of China. Since poor health standards permeate into the export economy, China's customers are going to refuse to buy products (e.g. fish, toys) tainted by pollution and the Chinese export economy will deteriorate.

In China the communist dictatorship, and historically subservient population, has accepted the current condition as a price for economic/social/political stability. As the country modernizes and changes, the question is will the environmental cost be too high and the political system too rigid for the good of the country?

\section{Political}

Historically, there has been a correlation between the political system and economic system of any country. An economic system based on capitalism and free enterprise required a democratic political system and free will to support it. Freedom of choice is the foundation of capitalism and a dictatorship, by definition, does not allow for freedom of choice. 
China today is a paradox. It is ruled by a one party dictatorial political system. On the other hand China, for the past ten years, has liberalized its economy. It has allowed for the private ownership of resources, an anathema to their communist credo, and for the accumulation of wealth by private individuals. In a country where all the people are considered equal the rich are no longer an anomaly. This conflict between the two systems will need to be resolved. It is the "irresistible" force for freedom of choice as embodied by materialism and capitalism facing the "immovable" object that is a communist dictatorship. In 1998 at Tiannamen Square the state (i.e. immovable object) won the battle, the question for the future is who will win the war?

\section{Culture}

The Chinese culture is based on the principals of sacrifice and submission to authority. Furthermore, following the Buddhist, Confucian, Han and Tao philosophies, the Chinese have a great reverence for age while viewing women as subservient. These attitudes enable the Chinese to sacrifice the well being of the individual for the benefit of society. Historically poor, at least in the modern era, China has been able to tap a large pool of workers to create a mass manufacturing system operating at very low labor costs. This approach, coupled with high savings from economies of scale production has made China the manufacturing factory for most of the world.

However, culture evolves over time. As China westernizes and its population is exposed to the western culture their outlook changes. The younger Chinese have become more materialistic, individualistic and rebellious. With increasing urbanization, the traditional multigenerational household is disappearing. Thus, the young will not have traditional role models near by, they will tend to emulate celebrity figures rather that the elderly. They will feel less responsible for taking care of their parents and grandparents as they age. As the population ages, a massive problem is emerging. There's no structured, government program (e.g. social security, Medicare, etc.) for the elderly to rely on. With young people no longer feeling obligated to sacrifice their life style for the "greater good" a generational crisis is brewing.

China is riding high today on the basis of its low cost manufacturing advantage. However, there's always competition around the corner. Already Viet Nam today, and possibly North Korea tomorrow, challenge China's dominant manufacturing position. There are also issues regarding the safety of Chinese manufactured goods (e.g. lead in toys, poison in fish). This is another fall out of the pollution situation mentioned above and the cultural imperative not to question authority. For the economic miracle to continue, China needs to address these issues and, as importantly, move to the next level (i.e. technology based) of economic activity.

\section{Technology}

Future development and a continuing strategic advantage will depend on technological advances. For innovation to occur there has to be a culture of curiosity that is rebellious by nature. The Chinese, who were the technological innovators earlier in their history, have been brow beaten into submissiveness by over 50 years of communism and centuries of colonial domination by the western powers. Today China is at a crossroads. The government is pouring billions of dollars into $\mathrm{R} \& \mathrm{D}$ projects and Chinese students flock to western schools to study the latest developments in science and engineering. Yet it is very difficult to change a nation's psychology and character. To be innovative the younger generation of Chinese will need to overcome their cultural heritage and become more independent in the future.

\section{CONCLUSIONS}

China is a big country in many ways. It has the largest population of any country and one of the largest land areas. It is the leading exporter in international trade and its GDP ranks in the top five. It is the largest market for cellular phones, has the world's most populated cities and yet hundreds of millions Chinese peasants live in dire poverty (less than $\$ 2 /$ day). China is a communist dictatorship that in the past has brutally enforced its will (e.g. one child law) on the population. For China to succeed it was a government bound by the "rule of law" and not have a "law of rule". 
The miracle of China is very visible by viewing the skyline of Shanghai or seeing the plethora of "Made in China" labels on everything. The mirage that is China is seen when visiting the countryside and seeing the poverty of the peasants. There are two China's today and the question is which will emerge in the future?

In the late 1980's it was fashionable to predict that another Asian Colossus (i.e. Japan) will be the next super state and will over take America by the end of the $20^{\text {th }}$ century. In reality, while Japan today is the world's second largest economy, the Japanese sun is setting due to an aging population. China's future is more cloudy but its trajectory may be similar to Japan's.

China will continue to grow and will likely even overtake Japan in terms of total national GDP and hundreds of millions pf Chinese will improve their lives. This is the miracle of China. However, it will likely not completely break its cultural and political restraints and thus not overtake the US. China's GDP per capita will place it in the middle range of countries and not among the wealthiest. They will still have hundreds of millions of very poor citizens living in a much polluted country. That is the mirage of high expectations of China in the $21^{\text {st }}$ century.

\section{REFERENCES}

1. Bhagwati, Jagdish. (2007, July 8). Made in China. Newsweek.

2. Bradsher, Keith. (2007, August 14). Surge in consumer prices stirs China's concern about overheated economy. New York Times.

3. Economist. (2007, March 31). Reaching for a renaissance - a special report on China and its region.

4. French, Howard W. (2007, March 22). China scrambles for stability as its workers age. New York Times.

5. Kahn, Joseph and Yardley, Jim. (2007, August 26). As China roars, pollution reaches deadly extremes. New York Times.

6. $\quad$ Sachs, Jeffrey D., (2004, January 12). Welcome to the Asian century. Fortune Magazine. p. 53.

7. Schell, Orville. (2007, April 16). When China's rivers run dry. Newsweek. P. 84-86.

8. Thurow, Lester. (2007, August 19). A Chinese century? Maybe it's the next one. New York Times. p. 4.

9. Yardley, Jim. (2005, January 31). Fearing future China starts to give girls their due. New York Times. 